\title{
Do Firm Size Influence Financial Analyst Research Reports and Subsequent Stock Performance
}

\author{
Huai-Chun Lo ${ }^{1}$ \\ ${ }^{1}$ Division of Finance, College of Management, Yuan Ze University, Taiwan \\ Correspondence: Huai-Chun Lo, Division of Finance, College of Management, Yuan Ze University, Taiwan
}

Received: September 2, 2017

Accepted: September 26, 2017

Online Published: September 29, 2017

doi:10.5430/afr.v6n4p181

URL: https://doi.org/10.5430/afr.v6n4p181

\begin{abstract}
This study investigates whether analysts issue more favorable research reports for small stocks than for large stocks. Small stocks tend not to attract investors due to their size, bad liquidity, easily manipulated price, insufficient information, and high-uncertainty risk. If analysts follow a small stock, it might be because the firm is thought to have good prospects. This study finds that analysts report more positively on small stocks, including in their stock recommendations and earnings growth forecasts. The empirical results show that small stocks perform better in the following year than do other stocks but that this is not the case for operating performance. This finding suggests that analysts are more likely to recommend under-valued stocks, but this may not imply that the operating performance of these stocks will improve the following year.
\end{abstract}

Keywords: Analyst research report, Analyst coverage, Small stock, Stock recommendation

\section{Introduction}

Analysts serve as third-party information providers (Arya \& Mittendorf, 2007), and numerous investors rely heavily on analyst research to make investment decisions. Luo, Wang, Raithel and Zheng (2015) argue that financial analysts gather corporate social performance information and transmit it to investors through their research reports. Caylor, Cecchini and Winchel (2017) find that qualitative statements in an analyst research report generate valuable information for profitable trading strategies. On the other hand, financial analysts may has the influence on the real economy. He and Tian (2013) suggests that analysts coverage influences firm innovation performance because the pressure on managers to meet short-term goals. This study investigates whether analysts issue more favorable research reports for small stocks than for large stocks. The study further examines stock performance and operating performance in the following year to determine whether analysts choose qualified and profitable small stocks for investors.

When analyzing covered stocks, analysts have to collect information from varied sources, including internal and external sources, to assess their economic feasibility and investment potential. Both brokers and analysts are constrained by resource restrictions, such as limited human resources and time. However, all stocks have costs and benefits. The decision to follow a firm depends on firm characteristics, and the barriers to stock analysis differ across firms. McNichols and O'Brien (1997) assume that a stock is worth analyzing only when the information value is above a certain threshold. Analysts weigh the opportunity costs and benefits when deciding whether a stock should be included in a research portfolio. Lang, Lins and Miller (2004) find that firms exhibiting poor internal governance are less likely to be followed by analysts. Therefore, the stocks of large firms attract many analysts; their benefits include trading commissions and potential consulting or underwriting business.

Fortin and Roth (2011) find that analysts tend to follow large and growth stocks. Firms with growth potential are more likely to be followed by analysts due to investors' interest and the potential for future investment banking deals (Lehavy, Li \& Merkley, 2011). Following such firms is less expensive for analysts because it is easy for them to collect information on their stocks; thus, such firms attract many analysts. Yu's (2008) US study finds that firms that are followed by more analysts are less likely to manipulate their earnings. Alford and Berger (1999) find that higher firm size is associated with greater forecast accuracy and that analysts prefer to follow firms with fewer uncertainties. Lee and So (2017) find that information from analyst coverage helps predict a stock's expected return, especially for stocks that were greatly underpriced.

On the other hand, studies have also found that small cap firm managers generally have difficulty attracting analyst 
coverage (Bhushan, 1989), a problem that worsened for small firms during the period of brokerage firm retrenchment (Fortin \& Roth, 2011). However, some analysts are sophisticated market participants who notice certain small stocks and release reports recommending them to investors. O'Brien and Tan (2015) show that geographic proximity affects analyst coverage decisions, particularly for small and less visible firms. Under the self-selection incentive (Hayes, 1998; McNichols \& O’Brien, 1997), analysts prefer to cover firms that are expected to perform well and to drop firms with poor prospects. Thus, if analysts are following small firms at an information disadvantage, it might be because these firms are considered to have good prospects or the analysts have private information regarding their stock. Therefore, a small stock is expected to be a better prospect when it is included as an investment target (McNichols \& O'Brien, 1997). This study empirically shows that analysts are more likely to issue favorable recommendations and earnings growth forecasts for small stocks.

Analysts always provide several reasons why investors should follow their recommendations. However, small stocks tend not to attract investors due to their size, bad liquidity, easily manipulated price, insufficient information, and high-uncertainty risk. Analysts must convey more good news about small stocks to attract hesitant investors and thus earn higher commissions. This study finds that analysts are more likely to issue optimistic earnings growth forecasts for small stocks than for large stocks to attract more investors, even when the stocks have the same rating. The results are consistent with self-selection hypothesis of McNichols \& O'Brien (1997) that analysts prefer to cover firms that are expected to perform well and to drop firms with poor prospects. Specially, if analysts are following small firms at an information disadvantage, it might be because these firms are thought to have good prospects.

This study's empirical results show that the performance of small stocks in the following year is better than that of other stocks, even when stock returns are adjusted according to different risk factors. The finding is also consistent with Demiroglu and Ryngaert (2010) that the neglected stocks experience significant liquidity improvement and abnormal returns subsequent to the first analyst coverage of them. However, the operating performance of small stocks in the following year is worse than that of others. These inconsistent results indicate that financial analysts tend to recommend undervalued stocks, but this may not imply that the operating performance of these stocks will improve the following year.

This study contributes to the literature on how firm size influences analyst coverage decisions and on the effectiveness of analyst stock recommendations. This study also contributes by helping investors better understand analyst research reports on small stocks. Being able to interpret analyst reports correctly is crucial for investors' investment decisions.

The rest of this paper is organized as follows. Section 2 reviews the literature and develops hypotheses. The study's data collection and research design are described in Section 3. Section 4 presents the empirical results. Finally, Section 5 concludes the paper.

\section{Literature Review and Hypothesis Development}

Studies have found that many factors can influence the quality of analyst research reports. Bradley, Gokkaya and Liu (2017) find that having industry experience helps analysts issue more accurate earnings forecasts. Merkley, Michaely and Pacelli (2017) find that spillover effects caused by a change in a financial analyst's target industry significantly affect the quality of the analyst's financial reports. Rubin, Segal and Segal (2017) show that stock markets respond more to analysts who are more likely to revise earnings forecasts due to unanticipated news because these analysts are able to issue more timely and accurate forecasts.

Analysts may strategize their reporting to investor clients in order to profit, leading to a potential conflict of interest. This conflict flows from revenue-generating businesses and access to private information (Schipper, 1991). Rees, Sharp and Wong (2017) show that, to favor firm management and access private information, security analysts tend to disclose downgrading recommendations on weekends. Ioannou and Serafeim suggest that analysts are more likely to issue optimistic recommendations for firms with high CSR performance because of agency cost of CSR investments. Firth, Lin and Xuan (2012) also indicates the business relations between mutual funds and brokerage firms has influence on the optimism of analysts' recommendations. Hong (2003) finds that analysts who are relatively optimistic enjoy more favorable employment prospects. McNichols and O'Brien (1997) and Hayes (1998) show that optimistic bias is the result of self-selection, whereby analysts are more likely to follow firms that are expected to perform well and to terminate those viewed as poor prospects. Moreover, Diether, Malloy and Scherbina (2002) find that the optimistic bias is greater when earnings uncertainty, measured as the variance in earnings, is greater. Langberg and Sivaramakrishnan (2008) support McNichols and O'Brien (1997), finding that managers' voluntary disclosure decisions depend on the level of analyst scrutiny and that analysts who exert greater scrutiny are more likely to discover good news. 
The investors themselves may be part of the cause of analysts' optimistic bias. Mikhail, Walther and Willis (2007) finds that small investors do not fully account for the effects of analysts' incentives to increase the credibility of their reports. Moreover, the expected rate of return estimated by analysts' optimistic forecasts appears to be upward biased, thus raising firms' cost of capital (Claus \& Thomas, 2001). Easton et al. (2007) confirm this phenomenon and argue that the cross-sample differences in analysts' optimistic bias may lead to erroneous conclusions.

The decision environment is more uncertain for analyses of small firms than for those of large firms due to the inferior information environment of the former, which induces analysts to make greater efforts to collect information regarding small firms. Enterprises or large organizations are reluctant to purchase small stocks due to insufficient information and illiquidity. Thus, analysts hesitate to analyze such stocks because they imply fewer benefits and more costs. Analysts' coverage decisions are determined mainly based on benefits and costs; costs are incurred during information formation. Brokerages incur substantial expenses in analyzing stocks and offering recommendations to investors, and they expect changes in stock returns to align with their predictions. Therefore, profits or private information should be offered to analysts with resource constraints as incentives to expend greater efforts in following small firms. According to the self-selection incentive (Hayes, 1998; McNichols \& O'Brien, 1997), analysts prefer to cover firms that are expected to perform well and to drop firms with poor prospects. Thus, if analysts are following small firms at an information disadvantage, it might be because these firms are thought to have good prospects. Consequently, self-selection theory supports the notion that analysts report on small firms more positively. Therefore, this study proposes the following:

H1: Analysts are more likely to issue more favorable stock ratings for small firms.

$\mathrm{H} 2$ : Analysts are more likely to issue more optimistic earnings growth forecasts for small firms.

\section{Data and Research Design}

\subsection{Data}

This study collects financial data on North American firms covering 1994 to the end of 2016 from the Compustat database. Data on stock prices and stock returns covering 1994 to 2016 are collected from the Center for Research in Security Prices (CRSP). Data on stock recommendations, earnings forecasts, and earnings growth forecasts are taken from the detail file of the Institutional Broker Estimates System (I/B/E/S). Where an analyst issues more than one report for a specific stock within 182 days, the study considers only the latest in the fiscal year.

The sample comprises all firms in the Compustat database that were followed by at least one analyst within 182 days before the fiscal year end. Because the I/B/E/S stock ratings data begin in mid-1993, the sample period is from 1996 to 2016 to prevent rare observations in the initial years. This study also excludes ADRs in the sample because those firms may have business environments and economic conditions that differ from those of other North American firms. To exclude firms in financial distress, which might influence the results, this study excludes observations with a negative book value of total assets or book value of equity. Moreover, the stock price is above one dollar at the end of the fiscal year for each observation. This study also excludes financial institutions and banks as well as transportation and utilities firms because they face regulatory restrictions and have unique financial characteristics. To ensure that the results are not driven by outliers, this study winsorizes all continuous variables at $1 \%$ and $99 \%$.

\subsection{Research Design}

To examine hypothesis 1 , this study estimates the following model:

$$
R E C_{i t}=\beta_{0}+\beta_{1} \text { RSize }_{i t-1}+\sum \gamma_{k} \text { Control }_{i k}+\sum \phi_{p} \text { Ind }_{p, i t}+\sum \varphi_{q} \text { Year }_{q, i t}+\varepsilon_{i t},
$$

where REC is the mean score issued by financial ankalysts. Because analysts issue strong buy, buy, hold, sell, and strong sell opinions for each stock, this study assigns a score of 5 to 1 for strong buy to strong sell. If the stock receives more than one stock rating from different analysts, this study takes the mean score among these scores. RSize is a decile ranking variable that corresponds to the levels of firms' total assets from low to high. Specifically, this study divides the observations into 10 equally sized subsamples in each year with the same industry. The value of RSize is equal to 10 (1) for the largest (smallest) subsamples. Industries are defined according to the 48 -industry classification in Fama and French (1997). Hypothesis 1 predicts that $\beta_{1}$ is negative.

Following Fortin and Roth (2011), this study includes several control variables that may influence analysts' reports. Control variables include book-to-market ratio (BM), logarithm of firm age (LogFirmAge), return on assets (ROA), sales growth rate (SaleG), debt ratio (DebtR), Altman's (1968) z-score (Zscore), the volatility of a firm's quarterly ROA (STD_ROA), and the KZ index (KZ), a measure of capital constraints developed by Kaplan and Zingales (1997). To prevent the intertemporal effect, industry fixed effects and year fixed effects are included in the model. 
The following model is estimated to test hypothesis 2 :

$$
\text { Growth }_{i t}=\beta_{0}+\beta_{1} \text { RSize }_{i t-1}+\sum \gamma_{k} \text { Control }_{i k}+\sum \phi_{p} \text { Ind }_{p, i t}+\sum \varphi_{q} \text { Year }_{q, i t}+\varepsilon_{i t}
$$

where GrowthF is mean earnings growth forecasts isstied by analysts within the last ${ }^{q} 182$ days before fiscal year end in year t. As in Eq. (1), control variables, industry fixed effects, and year fixed effects are also included in the model. This study estimates Eq. (1) and Eq. (2) through ordinary least square (OLS) methodology, and use White heteroscedasticity-consistent (HC) standard errors.

\section{Empirical Results}

\subsection{Descriptive Statistics}

This section presents the empirical results. Table 1 shows summary statistics and correlation coefficients for the sample data. Panel A of Table 1 shows the descriptive statistics. The sample comprises 32,908 firm-year records spanning 1996 to the end of 2016, including 6,642 analysts and 8,542 firms. The mean and median of REC is 3.78, which is close 4 and suggests that buy and strong buy stock ratings comprise most of the stock recommendations. The mean and median of earnings growth forecasts are $18.22 \%$ and $15 \%$ respectively, indicating that analysts are confident about the long-term prospects of their coverage. The average value of subsequent changes of ROA is slightly below 0 , suggesting that business is highly competitive during the sample period.

The mean and median values of RSize reflects the value is between 1 and 10. The average value of BM indicates that the book value of equity accounts for only half of the market value. The mean logged value of 2.79 for years of establishment (LogFirmAge) suggests that the sample firms have been in business for 20.4 years. The mean and median of ROA are $3.28 \%$ and $5.35 \%$ respectively. The mean sales growth rate is $18 \%$, while the median value is less than $10 \%$, suggesting that certain firms expanded rapidly. The average debt ratio of $47.3 \%$ shows that almost half of the firms' assets rely on financial leverage. For the firm risk measures, the mean z-score, standard deviation of quarterly ROA, and $\mathrm{KZ}$ are 5.36, 0.0267 , and 0.74 respectively.

Panel B of Table 1 shows the correlation coefficients between the variables. RSize is negatively associated with REC, and GrowthF, tentatively supporting hypotheses 1 to 2 . This table shows that most of the correlation coefficients between the variables are below 0.4, suggesting that the multicollinearity problem is minimal. However, several variables are highly correlated, including RSize and LogFirmAge, Zscore and ROA, KZ and DebtR, and KZ and Zscore. Because they may capture different effects of analysts' reports, this study retains all the control variables in the full model. However, the study drops variables that are highly correlated in the auxiliary regression to ensure that the multicollinearity problem does not influence the empirical results.

Table 2 presents the preliminary test of mean analyst stock rating and earnings growth forecasts for different firm sizes. The median value is presented in italics. Observations are divided into five equally sized sub-samples within each industry in each year corresponding to the levels of firms' mean stock ratings (from low to high). The mean and median results in Panel A show that analyst stock ratings and earnings growth forecasts are negatively associated with firm size. Quintile 1 comprises the smallest firm in each industry, with a sub-sample of the highest mean stock rating and earnings growth forecast. When the observations are divided into only two groups, a significant difference appears between small and large firms. Panel B further classifies the observations into three equally sized groups within each industry according to the stock rating in each year. Thus, there are 15 sub-samples with different levels of firm size and stock rating in Panel B. The results show that, even for different stock ratings, the mean and median values of earnings growth forecasts still decrease with firm size. The results shown in Table 2 support the hypotheses. 
Table 1. Descriptive Statistics

\begin{tabular}{lccccc}
\hline $\begin{array}{l}\text { Panel A Summary statistics } \\
\text { Variable }\end{array}$ & Mean & Q1 & Q2 & Q3 & Std. \\
\hline REC & 3.7812 & 3.7857 & 3.4375 & 4.1429 & 0.51 \\
GrowthF & 18.2177 & 15.0000 & 11.0000 & 22.0000 & 12.47 \\
ChgROA & -0.0105 & -0.0027 & -0.0391 & 0.0228 & 0.12 \\
AR & 0.4702 & 0.2860 & -1.5699 & 2.2365 & 3.92 \\
RSIZE & 5.5198 & 6.0000 & 3.0000 & 8.0000 & 2.81 \\
BM & 0.4934 & 0.3992 & 0.2437 & 0.6306 & 0.37 \\
LogFirmAge & 2.7975 & 2.7726 & 2.1972 & 3.3673 & 0.74 \\
ROA & 0.0328 & 0.0535 & 0.0046 & 0.0996 & 0.14 \\
SaleG & 0.1811 & 0.0984 & 0.0058 & 0.2450 & 0.38 \\
DebtR & 0.4730 & 0.4815 & 0.3052 & 0.6256 & 0.21 \\
Zscore & 5.3619 & 3.6621 & 2.2559 & 6.1017 & 5.95 \\
STD_ROA & 0.0267 & 0.0139 & 0.0069 & 0.0301 & 0.04 \\
KZ & 0.7394 & 0.7538 & 0.0936 & 1.4542 & 1.11
\end{tabular}

Panel B Correlation coefficients-Pearson (above) / Spearman (below) Correlations

\begin{tabular}{llrrrrrrrrrrrrr}
\multicolumn{1}{c}{ Variable } & \multicolumn{1}{c}{$(1)$} & $(2)$ & $(3)$ & $(4)$ & $(5)$ & $(6)$ & $(7)$ & $(8)$ & $(9)$ & $(10)$ & $(11)$ & $(12)$ & $(13)$ \\
\hline (1) & REC & 1 & 0.26 & -0.06 & 0.26 & -0.16 & -0.21 & -0.18 & 0.11 & 0.28 & -0.10 & 0.17 & -0.01 & 0.05 \\
(2) & GrowthF & 0.34 & 1 & -0.01 & 0.13 & -0.28 & -0.15 & -0.36 & -0.19 & 0.40 & -0.25 & 0.27 & 0.23 & 0.02 \\
(3) & ChgROA & -0.07 & -0.05 & 1 & 0.02 & 0.05 & -0.05 & 0.03 & -0.41 & -0.07 & 0.09 & -0.08 & 0.15 & 0.10 \\
(4) & AR & 0.25 & 0.13 & 0.06 & 1 & -0.07 & -0.38 & -0.06 & 0.18 & 0.17 & -0.07 & 0.29 & 0.01 & -0.01 \\
(5) RSIZE & -0.16 & -0.32 & 0.06 & -0.04 & 1 & -0.04 & 0.41 & 0.13 & -0.17 & 0.34 & -0.19 & -0.22 & 0.13 \\
(6) & BM & -0.19 & -0.22 & -0.05 & -0.37 & -0.02 & 1 & -0.01 & -0.20 & -0.14 & -0.04 & -0.32 & 0.01 & 0.02 \\
(7) & LogFirmAge & -0.17 & -0.44 & 0.04 & -0.04 & 0.41 & 0.03 & 1 & 0.18 & -0.30 & 0.24 & -0.17 & -0.25 & -0.08 \\
(8) ROA & 0.17 & -0.01 & -0.32 & 0.23 & 0.07 & -0.36 & 0.13 & 1 & -0.04 & -0.07 & 0.25 & -0.46 & -0.22 \\
(9) SaleG & 0.35 & 0.44 & -0.12 & 0.20 & -0.17 & -0.23 & -0.28 & 0.24 & 1 & -0.10 & 0.18 & 0.14 & 0.01 \\
(10) DebtR & -0.09 & -0.32 & 0.08 & -0.05 & 0.34 & -0.08 & 0.25 & -0.17 & -0.13 & 1 & -0.58 & -0.11 & 0.59 \\
(11) Zscore & 0.15 & 0.26 & -0.09 & 0.26 & -0.18 & -0.40 & -0.08 & 0.53 & 0.20 & -0.65 & 1 & 0.01 & -0.28 \\
(12) STD_ROA & -0.01 & 0.24 & 0.09 & -0.03 & -0.28 & -0.01 & -0.28 & -0.31 & 0.01 & -0.16 & -0.05 & 1 & 0.01 \\
(13) & KZ & 0.07 & 0.00 & 0.09 & 0.01 & 0.14 & -0.05 & -0.07 & -0.29 & 0.03 & 0.64 & -0.50 & -0.04 & 1
\end{tabular}

Note: This table provides descriptive statistics. Panel A is summary statistics of variables in this study. Panel B is correlation coefficients between variables. REC is mean score that are issue by financial analyst; GrowthF is mean earnings growth forecasts issued by different analysts; ChgROA is the change of return on asset from year t to year $\mathrm{t}+1$; AR is annualized abnormal returns in subsequent year obtained from four factor model (Fama and French, 1992, 1993; Carhart, 1997); RSize is a decile ranking variable that corresponds to the levels of firms' total asset from low to high; BM is book to market ratio; LogFirmAge is logarithm of firm age; ROA is return on asset; SaleG is sales growth rate; DebtR is debt ratio, Zscore is Z-score to measure financial risk developed by Altman's (1968), STD_ROA is volatility of a firm's quarterly ROA, $\mathrm{KZ}$ is $\mathrm{KZ}$ index (KZ) to measure capital constraints develop by Kaplan and Zingales (1997). 
Table 2. Mean and median of analyst recommendations and earnings growth forecasts

\begin{tabular}{|c|c|c|c|c|c|c|c|c|c|}
\hline \multicolumn{10}{|c|}{ Panel A Grouped by firm size } \\
\hline \multirow[b]{2}{*}{ Variable } & \multicolumn{5}{|c|}{$\underline{5 \text { group }}$} & \multicolumn{4}{|c|}{$\underline{2 \text { group }}$} \\
\hline & $\begin{array}{c}\text { Quintile } \\
1\end{array}$ & $\begin{array}{c}\text { Quintile } \\
2\end{array}$ & $\begin{array}{c}\text { Quintile } \\
3\end{array}$ & $\begin{array}{c}\text { Quintile } \\
4\end{array}$ & Quintile 5 & Low & High & Diff & Statistics \\
\hline \multirow[t]{2}{*}{ REC } & 3.94 & 3.81 & 3.75 & 3.70 & 3.71 & 3.8532 & 3.7129 & 0.1403 & $24.86 * * *$ \\
\hline & 4.00 & 3.83 & 3.75 & 3.71 & 3.74 & 3.8750 & 3.7273 & 0.1477 & $24.89 * * *$ \\
\hline \multirow[t]{2}{*}{ GrowthF } & 23.60 & 20.09 & 18.09 & 15.91 & 13.57 & 21.21 & 15.40 & 5.81 & $43.08 * * *$ \\
\hline & 20.00 & 17.50 & 15.00 & 14.50 & 12.50 & 19.00 & 14.00 & 5.00 & $48.98 * * *$ \\
\hline
\end{tabular}

Panel B Mean and median of earnings growth forecasts grouped by firm size and stock rating

\begin{tabular}{|c|c|c|c|c|c|c|c|c|c|}
\hline \multirow[b]{2}{*}{$\begin{array}{l}\text { Stock } \\
\text { Rating }\end{array}$} & \multicolumn{5}{|c|}{$\underline{5 \text { group }}$} & \multicolumn{4}{|c|}{2 group } \\
\hline & $\begin{array}{c}\text { Quintile } \\
1\end{array}$ & $\begin{array}{c}\text { Quintile } \\
2\end{array}$ & $\begin{array}{c}\text { Quintile } \\
3\end{array}$ & $\begin{array}{c}\text { Quintile } \\
4\end{array}$ & Quintile 5 & Low & High & Diff & Statistics \\
\hline \multirow{2}{*}{ Low } & 20.42 & 17.61 & 15.61 & 13.84 & 11.60 & 18.27 & 13.28 & 5.00 & $21.37 * * *$ \\
\hline & 18.00 & 15.00 & 13.80 & 12.13 & 11.00 & 15.00 & 12.00 & 3.00 & $22.97 * * *$ \\
\hline \multirow{2}{*}{ Median } & 23.59 & 20.02 & 18.41 & 16.55 & 13.93 & 21.05 & 15.86 & 5.19 & $22.43 * * *$ \\
\hline & 20.00 & 17.50 & 15.00 & 15.00 & 13.00 & 18.68 & 14.00 & 4.68 & $25.60 * * *$ \\
\hline \multirow{2}{*}{ High } & 25.22 & 22.20 & 20.48 & 17.96 & 15.71 & 23.45 & 17.66 & 5.79 & $22.36 * * *$ \\
\hline & 22.00 & 20.00 & 17.81 & 16.00 & 14.94 & 20.00 & 15.00 & 5.00 & $-26.02 * * *$ \\
\hline
\end{tabular}

Note: This table provides mean and median of analyst recommendations and earnings growth forecasts,

Panel A is grouped by firm size, and Panel B is grouped by firm size and stock rating. Median value is also presented in italics in this table. REC is mean score that are issue by financial analyst; GrowthF is mean earnings growth forecasts issued by different analysts. Statistics is t statistics in mean test and chi-square statistics in median value test. $* * *, * *, *$ indicate statistical significance at the 1 percent, 5 percent, and 10 percent two-tailed confidence levels, respectively.

\subsection{Empirical Results of Hypotheses}

Table 3 presents the regression results for model (1), which tests hypothesis 1. A negative relationship appears between firm size ranking (RSize) and stock ratings issued by analysts, regardless of whether full or partial control variables are included in the regression. This suggests that analysts tend to issue buy or strong buy stock recommendations for small firms, supporting hypothesis 1 . The results are consistent with self-selection hypothesis of McNichols \& O'Brien (1997) that analysts prefer to cover firms that are expected to perform well and to drop firms with poor prospects. Specially, if analysts are following small firms at an information disadvantage, it might be because these firms are thought to have good prospects. This table also shows analysts are more likely to issue favorable recommendations to firms with high ROA, high sales growth (SaleG), low financial leverage (DebtR), low financial risk (Zscore), low operating risk (STD_ROA).

To examine hypothesis 2, the results of model (2) are shown in Panel A of Table 4. There is a significantly negative coefficient on RSize, regardless of whether full or partial control variables are included in the regression. The regression results indicate that the optimism of earnings growth forecasts decrease with firm size. These results are consistent with the argument of hypothesis 2 that earnings growth forecasts are more optimistic for small firms. The results of control variables show that the optimism of earnings forecasts growth rate are positively associated with SaleG, Zscore, STD_ROA, KZ, while it is negatively associated with BM, LogFirmAge, ROA, DebtR. Because analysts' levels of optimism may differ for different stock ratings, this study controls for the effect of stock ratings. The observations are first divided into three equally sized sub-samples within each industry in each year corresponding to the levels of the firms' mean stock ratings (from low to high). Model (2) is then examined again for each sub-sample. The results are presented in Panel B. The estimated coefficients on RSize are significantly negative regardless of which sub-sample is used. These empirical results support hypothesis 2 , after the stock rating level is controlled for. 
Table 3. Regression results of stock rating on firm size

\begin{tabular}{|c|c|c|c|c|c|c|c|c|}
\hline Variable & Coef. & $\mathrm{t}$ & Coef. & $\mathrm{t}$ & Coef. & $\mathrm{t}$ & Coef. & $\mathrm{t}$ \\
\hline Intercept & 4.0218 & $117.15 * * *$ & 4.1586 & $120.18 * * *$ & 4.1805 & $119.42 * * *$ & 4.2593 & $118.01 * * *$ \\
\hline RSIZE & -0.0286 & $-30.33 * * *$ & -0.0244 & $-23.31 * * *$ & -0.0261 & $-25.96 * * *$ & -0.0237 & $-22.07 * * *$ \\
\hline $\mathrm{BM}$ & & & -0.2833 & $-37.25 * * *$ & -0.2779 & $-34.53 * * *$ & -0.2931 & $-36.63 * * *$ \\
\hline LogFirmAge & & & -0.0242 & $-5.53 * * *$ & & & -0.0085 & $-1.92 *$ \\
\hline ROA & & & & & 0.3556 & $16.33 * * *$ & 0.4647 & $21.07 * * *$ \\
\hline SaleG & & & 0.2443 & $33.84 * * *$ & 0.2560 & $36.07 * * *$ & 0.2493 & $34.97 * * *$ \\
\hline DebtR & & & & & -0.1240 & $-7.09 * * *$ & -0.3943 & $-18.79 * * *$ \\
\hline Zscore & & & 0.0017 & $3.55 * * *$ & -0.0030 & $-4.92 * * *$ & -0.0053 & $-8.80 * * *$ \\
\hline STD_ROA & & & -1.1848 & $-15.67 * * *$ & -0.5770 & $-7.01 * * *$ & -0.5188 & $-6.34 * * *$ \\
\hline $\mathrm{KZ}$ & & & & & & & 0.0708 & $23.18 * * *$ \\
\hline Year & Yes & & Yes & & Yes & & Yes & \\
\hline Ind & Yes & & Yes & & Yes & & Yes & \\
\hline Adj R-Sq & 0.1167 & & 0.2033 & & 0.2105 & & 0.2242 & \\
\hline $\mathrm{N}$ & 32,908 & & 32,908 & & 32,908 & & 32,908 & \\
\hline
\end{tabular}

Note: This table provides regression results of model (1). The dependent variable is REC which is mean score that are issue by financial analyst. RSize is a decile ranking variable that corresponds to the levels of firms' total asset from low to high; BM is book to market ratio; LogFirmAge is logarithm of firm age; ROA is return on asset; SaleG is sales growth rate; DebtR is debt ratio, Zscore is Z-score to measure financial risk developed by Altman's (1968), STD_ROA is volatility of a firm's quarterly ROA, KZ is KZ index to measure capital constraints develop by Kaplan and Zingales (1997). ***,**,* indicate statistical significance at the 1 percent, 5 percent, and 10 percent two-tailed confidence levels, respectively. 
Table 4. Regression results of earnings growth forecasts on firm size

\begin{tabular}{|c|c|c|c|c|c|c|c|c|}
\hline \multicolumn{9}{|c|}{ Panel A Full sample } \\
\hline Variable & Coef. & $\mathrm{t}$ & Coef. & $\mathrm{t}$ & Coef. & $\mathrm{t}$ & Coef. & $\mathrm{t}$ \\
\hline Intercept & 19.4841 & $24.43 * * *$ & 21.9119 & $28.00 * * *$ & 19.4544 & $24.64 * * *$ & 24.2266 & $29.85 * * *$ \\
\hline RSIZE & -1.2230 & $-55.80 * * *$ & -0.6325 & $-26.76 * * *$ & -0.7170 & $-31.63 * * *$ & -0.5391 & $-22.34 * * *$ \\
\hline BM & & & -2.9683 & $-17.26 * * *$ & -4.1642 & $-22.94 * * *$ & -4.5104 & $-25.06 * * *$ \\
\hline LogFirmAge & & & -2.2491 & $-22.72 * * *$ & & & -1.6057 & $-16.12 * * *$ \\
\hline ROA & & & & & -15.0670 & $-30.68 * * *$ & -12.4460 & $-25.10 * * *$ \\
\hline SaleG & & & 8.1992 & $50.21 * * *$ & 8.6803 & $54.22 * * *$ & 8.1724 & $50.97 * * *$ \\
\hline DebtR & & & & & -3.8110 & $-9.66 * * *$ & -8.6522 & $-18.34 * * *$ \\
\hline Zscore & & & 0.2069 & $18.78 * * *$ & 0.2411 & $17.69 * * *$ & 0.1918 & $14.05 * * *$ \\
\hline STD_ROA & & & 31.8385 & $18.62 * * *$ & 12.3377 & $6.65 * * *$ & 11.8443 & $6.44 * * *$ \\
\hline $\mathrm{KZ}$ & & & & & & & 1.3116 & $19.09 * * *$ \\
\hline Year & Yes & & Yes & & Yes & & Yes & \\
\hline Ind & Yes & & Yes & & Yes & & Yes & \\
\hline Adj R-Sq & 0.1944 & & 0.3111 & & 0.3211 & & 0.3368 & \\
\hline $\mathrm{N}$ & 32,908 & & 32,908 & & 32,908 & & 32,908 & \\
\hline
\end{tabular}

Panel B Sub-sample: grouped by different level of stock rating

\begin{tabular}{lcccccc} 
Stock rating & \multicolumn{2}{c}{ Low } & \multicolumn{3}{c}{ Median } & \multicolumn{2}{c}{ High } \\
Variable & Coef. & $\mathrm{t}$ & Coef. & $\mathrm{t}$ & Coef. & $\mathrm{t}$ \\
\hline Intercept & 19.4718 & $13.54 * * *$ & 23.8525 & $18.72 * * *$ & 27.3013 & $18.16 * * *$ \\
RSIZE & -0.4650 & $-10.66 * * *$ & -0.4358 & $-10.90 * * *$ & -0.5843 & $-13.56 * * *$ \\
BM & -3.4884 & $-13.04 * * *$ & -4.5834 & $-14.57 * * *$ & -4.4517 & $-10.82 * * *$ \\
LogFirmAge & -1.5553 & $-8.91 * * *$ & -1.6230 & $-10.04 * * *$ & -1.6081 & $-8.84 * * *$ \\
ROA & -14.2048 & $-14.83 * * *$ & -15.9788 & $-18.89 * * *$ & -10.3749 & $-12.62 * * *$ \\
SaleG & 8.9747 & $27.90 * * *$ & 7.6940 & $28.40 * * *$ & 6.9239 & $26.09 * * *$ \\
DebtR & -8.0280 & $-10.22 * * *$ & -8.7775 & $-11.10 * * *$ & -6.4659 & $-7.25 * * *$ \\
Zscore & 0.1745 & $6.22 * * *$ & 0.2390 & $10.59 * * *$ & 0.1836 & $8.04 * * *$ \\
STD_ROA & 6.2100 & $1.92 *$ & 11.7809 & $3.81 * * *$ & 17.9354 & $5.44 * * *$ \\
KZ & 1.0421 & $8.79 * * *$ & 1.2047 & $10.53 * * *$ & 1.0922 & $8.60 * * *$ \\
Year & Yes & & Yes & & Yes & \\
Ind & Yes & & Yes & & Yes & \\
Adj R-Sq & 0.2975 & & 0.3611 & & 0.3130 & \\
N & 10,681 & & 11,272 & & 10,955 &
\end{tabular}

Note: This table provides regression results of model (2). The dependent variable is GrowthF which is mean earnings growth forecasts issued by different analysts. RSize is a decile ranking variable that corresponds to the levels of firms' total asset from low to high; BM is book to market ratio; LogFirmAge is logarithm of firm age; ROA is return on asset; SaleG is sales growth rate; DebtR is debt ratio, Zscore is Z-score to measure financial risk developed by Altman's (1968), STD_ROA is volatility of a firm's quarterly ROA, KZ is KZ index to measure capital constraints develop by Kaplan and Zingales (1997). ***, **, * indicate statistical significance at the 1 percent, 5 percent, and 10 percent two-tailed confidence levels, respectively. 


\subsection{Empirical Results of Subsequent Stock Performance}

To investigate the performance of analysts' stock recommendations, this section examines the relationship between firm size and market-based stock performance in the subsequent year. Stock performance is measured using the following four-factor model (Fama \& French, 1992, 1993; Carhart, 1997):

$$
R_{i}-R_{f}=\alpha+\beta_{1}\left(R_{m}-R_{f}\right)+\beta_{2} S M B_{i t}+\beta_{3} H M L_{i t}+\beta_{4} U M D_{i t}+\varepsilon_{i},
$$

where $R_{i}$ are the daily returns of firm $i$ in year $t, R_{f}$ is the daily treasury bill interest rate, $R_{m}-R_{f}$ is the excess return on the market portfolio, and $\mathrm{R}_{\mathrm{m}}$ is the daily return of the NYSE/AMEX/NASDAQ value-weighted index. Fama and French $(1992,1993)$ provide a three-factor model that they suggest may explain the time series of stock returns. The three-factor model $R_{m}-R_{f}$ is the excess return on the market portfolio; SMB represents the size premium and is calculated as the difference between the return on a portfolio comprised of small stocks and the return on a portfolio comprised of large stocks; HML represents the value premium, calculated as the return on a portfolio of a high book-to-market ratio minus the return on a portfolio of low book-to-market stocks. Carhart (1997) extends the model by adding a momentum factor, UMD, to capture the momentum premium. UMD is defined as the return on a portfolio comprised of stocks with high returns less the return on a portfolio comprised of stocks with low returns. This study obtains $\alpha$ for each stock in the subsequent year as abnormal returns and then adjusts $\alpha$ to annualize abnormal returns. The returns are multiplied by 100 to make them percentages. The long-run stock performance was evaluated by considering only those observations that contained daily stock return rate data for at least one year (252 trading days) in the subsequent year.

Table 5 shows the mean and median abnormal returns for all firm sizes. Panel A splits the observations into five equally sized sub-samples corresponding to the firm size levels; the classification is the same as that seen in Table 2. The mean and median abnormal returns are shown in Panel A. Abnormal returns in the subsequent year are negatively monotonic with firm size. The largest abnormal returns occur in the sub-sample of Quintile 1 (small firms), measured by either mean or median value. A robustness test is performed for three-factor and one-factor abnormal returns; the results are qualitatively similar.

Similarly, Panel B splits the observations into two equally sized sub-samples. The difference between the small and large firms is significantly positive for both the mean and median value. These results confirm that small firms with analyst coverage enjoy higher abnormal returns in the subsequent year. Combining the results in Tables 3 and 5 shows that analysts are more likely to issue favorable reports for small firms and that small firms perform better in the subsequent year even when the size effect for the abnormal returns is controlled for.

In addition to stock returns, this study examines operating performance in the subsequent year to further investigate analyst performance. Following Chen and Liang (2016), operating performance is measured as change in return on assets (ChgROA) from year $t$ to year $t+1$. This study estimates the following model:

$$
\text { ChgROA }_{i t}=\beta_{0}+\beta_{1} \text { RSize }_{i t-1}+\sum_{k} \gamma_{k} \text { Control }_{i k}+\sum_{p} \phi_{p} \text { Ind }_{p, i t}+\sum_{q} \varphi_{q} \text { Year }_{q, i t}+\varepsilon_{i t} .
$$

The control variables are the same as those in Eq. (1). The regression results are shown in Panel A of Table 6, indicating that firm size (RSize) is significantly positively associated with subsequent operating performance. Panel A suggests that the smaller the firm, the worse the subsequent operating performance, in contrast to the subsequent stock performance results shown in Table 5. These inconsistent results indicate that financial analysts tend to recommend stocks that are undervalued, but this may not imply that the operating performance of these stocks will improve the following year. This study also uses the change in industry-adjusted ROA to measure operating performance. Industry-adjusted ROA is equal to the difference between a firm's ROA and the median ROA value in its corresponding industry. Panel B shows the estimation results, confirming that subsequent operating performance decreases as firm size decreases. 
Table 5. Mean and median of subsequent stock performance

\begin{tabular}{|c|c|c|c|c|c|}
\hline \multicolumn{6}{|c|}{ Panel A five groups corresponding to firm size } \\
\hline Firm size & Quintile 1 & Quintile 2 & Quintile 3 & Quintile 4 & Quintile 5 \\
\hline \multicolumn{6}{|c|}{ four factor abnormal returns } \\
\hline mean & 1.00223 & 0.53385 & 0.32977 & 0.35058 & 0.16229 \\
\hline $\mathrm{t}$ & $12.5286 * * *$ & $8.2667 * * *$ & $5.7945 * * *$ & $7.3686 * * *$ & $3.9786 * * *$ \\
\hline median & 0.53361 & 0.31284 & 0.24969 & 0.28392 & 0.16821 \\
\hline Chisq & $800563 * * *$ & $584600 * * *$ & $450773 * * *$ & $644358 * * *$ & $382898 * * *$ \\
\hline \multicolumn{6}{|c|}{ three factor abnormal returns } \\
\hline mean & 1.00241 & 0.52585 & 0.32374 & 0.32777 & 0.13901 \\
\hline $\mathrm{t}$ & $12.4283 * * *$ & $8.0443 * * *$ & $5.5859 * * *$ & $6.6775 * * *$ & $3.3011 * * *$ \\
\hline median & 0.56998 & 0.31781 & 0.2588 & 0.22866 & 0.15223 \\
\hline Chisq & $802214 * * *$ & $566589 * * *$ & $436865 * * *$ & $573932 * * *$ & $326098 * * *$ \\
\hline \multicolumn{6}{|c|}{ one factor abnormal returns } \\
\hline mean & 1.10243 & 0.5952 & 0.35094 & 0.37875 & 0.19229 \\
\hline $\mathrm{t}$ & $13.1955 * * *$ & $8.8322 * * *$ & $5.8626 * * *$ & $7.4286 * * *$ & $4.5652 * * *$ \\
\hline median & 0.61167 & 0.38796 & 0.23899 & 0.32956 & 0.20028 \\
\hline Chisq & $838640 * * *$ & $654551 * * *$ & $458464 * * *$ & $673648 * * *$ & $489616 * * *$ \\
\hline
\end{tabular}

Panel B two groups corresponding to firm size

$\begin{array}{lllll}\text { Firm size } & \text { Low } & \text { High } & \text { Diff } & \text { Statistics }\end{array}$

\begin{tabular}{ccccc}
\hline $\begin{array}{c}\text { four factor abnormal returns } \\
\text { mean } \\
\text { median }\end{array}$ & 0.6989 & 0.2604 & 0.4385 & 8.20 *** \\
\hline $\begin{array}{c}\text { three factor abnormal returns } \\
\text { mean } \\
\text { median }\end{array}$ & 1.2363 & 0.7293 & 0.5070 & 7.12 *** \\
\hline $\begin{array}{c}\text { one factor abnormal returns } \\
\text { mean }\end{array}$ & 0.6943 & 0.2403 & 0.4540 & 8.35 *** \\
median & 1.2276 & 0.6836 & 0.5440 & 7.34 *** \\
\hline
\end{tabular}

Note: This table provides mean and median of abnormal returns in year $\mathrm{t}+1$. Four factor abnormal returns are from four factor model (Fama and French, 1992, 1993; Carhart, 1997) according to Eq. (3). Three factor and one factor abnormal returns are also presented in this table. Panel A classifies observations into five groups according to firm size, and Panel B classifies observations into two groups according to firm size. Statistics is t statistics in mean test and chi-square statistics in median value test. ***,**,* indicate statistical significance at the 1 percent, 5 percent, and 10 percent two-tailed confidence levels, respectively. 
Table 6. Regression results of subsequent operating performance on firm size

\begin{tabular}{|c|c|c|c|c|c|c|c|c|}
\hline \multicolumn{9}{|c|}{ Panel A Subsequent change of ROA } \\
\hline Variable & Coef. & $\mathrm{t}$ & Coef. & $\mathrm{t}$ & Coef. & $\mathrm{t}$ & Coef. & $\mathrm{t}$ \\
\hline Intercept & 0.0066 & 0.43 & 0.0144 & 0.89 & 0.0228 & 1.55 & 0.0028 & 0.19 \\
\hline RSIZE & 0.0014 & $3.21 * * *$ & 0.0011 & $2.36 * *$ & 0.0026 & $6.33 * * *$ & 0.0020 & $4.48 * * *$ \\
\hline BM & & & -0.0290 & $-6.55 * * *$ & -0.0503 & $-11.97 * * *$ & -0.0502 & $-11.96 * * *$ \\
\hline LogFirmAge & & & 0.0014 & 0.70 & & & 0.0082 & $4.41 * * *$ \\
\hline ROA & & & & & -0.4148 & $-50.25 * * *$ & -0.4183 & $-50.02 * * *$ \\
\hline SaleG & & & -0.0111 & $-3.65 * * *$ & -0.0164 & $-6.10 * * *$ & -0.0144 & $-5.30 * * *$ \\
\hline DebtR & & & . & & 0.0010 & 0.13 & 0.0036 & 0.40 \\
\hline Zscore & & & -0.0017 & $-8.41 * * *$ & 0.0006 & $2.42 * *$ & 0.0006 & $2.70 * * *$ \\
\hline STD_ROA & & & 0.3043 & $8.51 * * *$ & -0.2349 & $-6.99 * * *$ & -0.2316 & $-6.88 * * *$ \\
\hline $\mathrm{KZ}$ & & & & & & & -0.0007 & -0.57 \\
\hline Year & Yes & & Yes & & Yes & & Yes & \\
\hline Ind & Yes & & Yes & & Yes & & Yes & \\
\hline Adj R-Sq & 0.0255 & & 0.0420 & & 0.2358 & & 0.2373 & \\
\hline $\mathrm{N}$ & 10,059 & & 10,059 & & 10,059 & & 10,059 & \\
\hline
\end{tabular}

Panel B Subsequent change of industry adjusted ROA

\begin{tabular}{lcccccccc} 
Variable & Coef. & $\mathrm{t}$ & Coef. & $\mathrm{t}$ & Coef. & $\mathrm{t}$ & \multicolumn{1}{c}{ Coef. } & \multicolumn{1}{c}{$\mathrm{t}$} \\
\hline Intercept & -0.0128 & -0.83 & -0.0053 & -0.32 & -0.0006 & -0.04 & -0.0199 & -1.29 \\
RSIZE & 0.0013 & $3.15 * * *$ & 0.0011 & $2.39 * *$ & 0.0025 & $6.03 * * *$ & 0.0019 & $4.24 * * *$ \\
BM & & & -0.0292 & $-6.59 * * *$ & -0.0491 & $-11.58 * * *$ & -0.0490 & $-11.57 * * *$ \\
LogFirmAge & & & 0.0014 & 0.67 & & & 0.0080 & $4.27 * * *$ \\
ROA & & & & & -0.4038 & $-48.50 * * *$ & -0.4071 & $-48.24 * * *$ \\
SaleG & & & -0.0078 & $-2.56 * *$ & -0.0130 & $-4.80 * * *$ & -0.0111 & $-4.04 * * *$ \\
DebtR & & & - & & 0.0061 & 0.80 & 0.0078 & 0.85 \\
Zscore & & -0.0016 & $-7.89 * * *$ & 0.0007 & $2.99 * * *$ & 0.0008 & $3.22 * * *$ \\
STD_ROA & & & 0.2803 & $7.82 * * *$ & -0.2449 & $-7.22 * * *$ & -0.2413 & $-7.10 * * *$ \\
KZ & & & & & & & -0.0005 & -0.38 \\
Year & Yes & Yes & & Yes & & Yes & \\
Ind & Yes & Yes & & Yes & & Yes & \\
Adj R-Sq & 0.0177 & 0.0322 & & 0.2175 & & 0.2188 & \\
N & 10,059 & 10,059 & & 10,059 & & 10,059 & \\
\hline
\end{tabular}

Note: This table provides regression results of model (4). The dependent variable in Panel A is ChgROA which is the change of return on asset from year $t$ to year $t+1$; the dependent variable in Panel B is ChgROAadj which is the change of industry adjusted return on asset from year $t$ to year $t+1$. RSize is a decile ranking variable that corresponds to the levels of firms' total asset from low to high; BM is book to market ratio; LogFirmAge is logarithm of firm age; ROA is return on asset; SaleG is sales growth rate; DebtR is debt ratio, Zscore is Z-score to measure financial risk developed by Altman's (1968), STD_ROA is volatility of a firm's quarterly ROA, KZ is KZ index to measure capital constraints develop by Kaplan and Zingales (1997). ***,**, * indicate statistical significance at the 1 percent, 5 percent, and 10 percent two-tailed confidence levels, respectively. 


\subsection{Sensitivity Test}

To ensure that the results are not sensitive to variable definition or econometric specification, this section performs several sensitivity tests. This study adopts several alternative definitions as a proxy of firm size. The first is the logarithm of firm value (logSize) at the beginning of the fiscal year. To prevent a nonlinear relationship, a dummy variable (DSize) representing a small firm is applied, equal to one if the firm's size is within the lowest $20 \%$ of the industry at the beginning of the fiscal year and 0 otherwise. McNichols and O'Brien (1997) find that market information may have more informational value than accounting-based information. Thus, the alternative measure is the logarithm of the market value of a firm's assets (LogMSize), equal to the sum of the market value of equity and book value of debts. The other firm size indicator are RMSize and DMSize which use the same definitions as RSize and DSize but are based on market value.

This study applies these alternative firm size proxies to replicate Tables 3,4 , and 6 . The results are presented in Table 7. Firm size is negatively associated with stock rating and earnings growth forecasts and positively associated with subsequent operating performance. Because DSize and DMSize are dummy variables indicating small firms, their estimated coefficients are negative in Panels A and B, while they are positive in Panels C and D. The results in Table 7 are consistent with the earlier results.

Earnings forecasts are an important component of analysts' reports. Table 8 performs another sensitivity test that estimates model (2), while Table 8 shows analyst forecast bias (Bias) used as a dependent variable. Bias is the mean difference between the consensus earnings forecast and the actual annual earnings of firm $\mathrm{i}$ in year $\mathrm{t}$. The consensus earnings forecast is the median value of all yearly forecasts issued by analysts for firm $\mathrm{i}$ within the last 91 days before fiscal year end in year t. Panel A is estimated from the full sample, and Panel B is estimated from the sub-sample that controls for different stock rating levels (as in Panel B of Table 4). The estimated results are similar to those in Table 4, showing that analysts are more optimistic in their earnings forecasts for small firms.

Table 7. Sensitive test by different firm size indicators

\begin{tabular}{|c|c|c|c|c|c|c|c|c|c|c|}
\hline \multicolumn{11}{|c|}{ Panel A Dependent variable: REC } \\
\hline Variable & Coef. & $\mathrm{t}$ & Coef. & $\mathrm{t}$ & Coef. & $\mathrm{t}$ & Coef. & $\mathrm{t}$ & Coef. & $\mathrm{t}$ \\
\hline Intercept & 4.4814 & $120.77 * * *$ & 4.1783 & $114.69 * * *$ & 4.2745 & $119.01 * * *$ & 4.5498 & $121.78 * * *$ & 4.1694 & $115.07 * * *$ \\
\hline LogSize & -0.0428 & $-21.23 * * *$ & & & & & & & & \\
\hline DSIZE & & & 0.1540 & $22.39 * * *$ & & & & & & \\
\hline RMSIZE & & & & & -0.0285 & $-27.50 * * *$ & & & & \\
\hline LogMSize & & & & & & & -0.0487 & $-25.10 * * *$ & & \\
\hline DMSIZE & & & & & & & & & 0.1824 & $26.98 * * *$ \\
\hline $\begin{array}{l}\text { Control } \\
\text { Variables }\end{array}$ & Yes & & Yes & & Yes & & Yes & & Yes & \\
\hline Year & Yes & & Yes & & Yes & & Yes & & Yes & \\
\hline Ind & Yes & & Yes & & Yes & & Yes & & Yes & \\
\hline Adj R-Sq & 0.2234 & & 0.2246 & & 0.2304 & & 0.2275 & & 0.2298 & \\
\hline $\mathrm{N}$ & 32,908 & & 32,908 & & 32,908 & & 32,908 & & 32,908 & \\
\hline \multicolumn{11}{|c|}{ Panel B Dependent variable: GrowthF } \\
\hline Variable & Coef. & $\mathrm{t}$ & Coef. & $\mathrm{t}$ & Coef. & $\mathrm{t}$ & Coef. & $\mathrm{t}$ & Coef. & $\mathrm{t}$ \\
\hline Intercept & 29.9689 & $36.00 * * *$ & 23.1240 & $28.12 * * *$ & 24.7850 & $30.45 * * *$ & 28.8646 & $34.17 * * *$ & 23.6940 & $28.83 * * *$ \\
\hline LogSize & -1.1327 & $-25.06 * * *$ & & & & & & & & \\
\hline DSIZE & & & 2.5423 & $16.38 * * *$ & & & & & & \\
\hline RMSIZE & & & & & -0.3779 & $-16.07 * * *$ & & & & \\
\hline LogMSize & & & & & & & -0.7290 & $-16.60 * * *$ & & \\
\hline DMSIZE & & & & & & & & & 1.9844 & $12.94 * * *$ \\
\hline $\begin{array}{l}\text { Control } \\
\text { Variables }\end{array}$ & Yes & & Yes & & Yes & . & Yes & & Yes & \\
\hline Year & Yes & & Yes & & Yes & & Yes & & Yes & \\
\hline Ind & Yes & & Yes & & Yes & & Yes & & Yes & \\
\hline Adj R-Sq & 0.3394 & & 0.3322 & & 0.3320 & & 0.3324 & & 0.3302 & \\
\hline $\mathrm{N}$ & 32,908 & & 32,908 & & 32,908 & & 32,908 & & 32,908 & \\
\hline
\end{tabular}




\begin{tabular}{|c|c|c|c|c|c|c|c|c|c|c|}
\hline \multicolumn{11}{|c|}{ Panel C Dependent variable: Subsequent change of ROA } \\
\hline Variable & Coef. & $\mathrm{t}$ & Coef. & $\mathrm{t}$ & Coef. & $\mathrm{t}$ & Coef. & $\mathrm{t}$ & Coef. & $\mathrm{t}$ \\
\hline Intercept & -0.0427 & $-4.90 * * *$ & -0.0052 & -0.61 & -0.0159 & $-1.88 *$ & -0.0354 & $-4.01 * * *$ & -0.0109 & -1.27 \\
\hline LogSize & 0.0059 & $12.55 * * *$ & & & & & & & & \\
\hline DSIZE & & & -0.0157 & $-9.67 * * *$ & & & & & & \\
\hline RMSIZE & & & & & 0.0019 & $7.86 * * *$ & & & & \\
\hline LogMSize & & & & & & & 0.0034 & $7.53 * * *$ & & \\
\hline DMSIZE & & & & & & & & & -0.0092 & $-5.74 * * *$ \\
\hline $\begin{array}{l}\text { Control } \\
\text { Variables }\end{array}$ & Yes & & Yes & & Yes & & Yes & & Yes & \\
\hline Year & Yes & & Yes & & Yes & & Yes & & Yes & \\
\hline Ind & Yes & & Yes & & Yes & & Yes & & Yes & \\
\hline Adj R-Sq & 0.2343 & & 0.2327 & & 0.2319 & & 0.2318 & & 0.2312 & \\
\hline $\mathrm{N}$ & 29,959 & & 29,959 & & 29,959 & & 29,959 & & 29,959 & \\
\hline \multicolumn{11}{|c|}{ Panel D Dependent variable: Subsequent change of industry adjusted ROA } \\
\hline Variable & Coef. & $\mathrm{t}$ & Coef. & $\mathrm{t}$ & Coef. & $\mathrm{t}$ & Coef. & $\mathrm{t}$ & Coef. & $\mathrm{t}$ \\
\hline Intercept & -0.0611 & $-6.93 * * *$ & -0.0255 & $-2.94 * * *$ & -0.0361 & $-4.20 * * *$ & -0.0538 & $-6.03 * * *$ & -0.0316 & $-3.65 * * *$ \\
\hline LogSize & 0.0055 & $11.63 * * *$ & & & & & & & & \\
\hline DSIZE & & & -0.0154 & $-9.36 * * *$ & & & & & & \\
\hline RMSIZE & & & & & 0.0018 & $7.06 * * *$ & & & & \\
\hline LogMSize & & & & & & & 0.0031 & $6.81 * * *$ & & \\
\hline DMSIZE & & & & & & & & & -0.0082 & $-5.05 * * *$ \\
\hline $\begin{array}{l}\text { Control } \\
\text { Variables }\end{array}$ & Yes & & Yes & & Yes & & Yes & & Yes & \\
\hline Year & Yes & & Yes & & Yes & & Yes & & Yes & \\
\hline Ind & Yes & & Yes & & Yes & & Yes & & Yes & \\
\hline Adj R-Sq & 0.2116 & & 0.2103 & & 0.2093 & & 0.2093 & & 0.2087 & \\
\hline $\mathrm{N}$ & 29,959 & & 29,959 & & 29,959 & & 29,959 & & 29,959 & \\
\hline
\end{tabular}

Note: This table provides regression results of model (1), model (2), and model (4). The dependent variables are as follows: REC in Panel A, GrowthF in Panel B, ChgROA in Panel C, ChgROAadj in Panel D. REC which is mean score that are issue by financial analyst; GrowthF is mean earnings growth forecasts issued by different analysts; ChgROA is the change of return on asset from year $t$ to year $t+1$; ChgROAadj which is the change of industry adjusted return on asset from year $t$ to year $t+1$. LogSize is the logarithm total asset in the beginning fiscal year. DSize is a dummy variable that equals one if firm size of a particular firm is within the lowest $20 \%$ of the industry in the beginning fiscal year, and 0 otherwise. LogMSize equals logarithm of the sum of market value of equity and book value of debts. DMSize is a dummy variable that equals one if market value of a particular firm is within the lowest $20 \%$ of the industry in the beginning fiscal year, and 0 otherwise. Control variables include: BM is book to market ratio; LogFirmAge is logarithm of firm age; ROA is return on asset; SaleG is sales growth rate; DebtR is debt ratio, Zscore is Z-score to measure financial risk developed by Altman's (1968), STD_ROA is volatility of a firm's quarterly ROA, KZ is KZ index to measure capital constraints develop by Kaplan and Zingales (1997). ***, **,* indicate statistical significance at the 1 percent, 5 percent, and 10 percent two-tailed confidence levels, respectively. 
Table 8. Sensitive test by earnings forecasts bias

\begin{tabular}{|c|c|c|c|c|c|c|c|c|}
\hline \multicolumn{9}{|c|}{ Panel A Full sample } \\
\hline Variable & Coef. & $\mathrm{t}$ & Coef. & $\mathrm{t}$ & Coef. & $\mathrm{t}$ & Coef. & $\mathrm{t}$ \\
\hline Intercept & -0.2977 & -1.33 & -0.8033 & $-3.44 * * *$ & -2.0917 & $-8.89 * * *$ & -2.0873 & $-8.53 * * *$ \\
\hline RSIZE & -0.0579 & $-9.44 * * *$ & -0.0326 & $-4.61 * * *$ & -0.0546 & $-8.09 * * *$ & -0.0542 & $-7.45 * * *$ \\
\hline BM & & & 0.9910 & $19.28 * * *$ & 1.0720 & $19.82 * * *$ & 1.0758 & $19.83 * * *$ \\
\hline LogFirmAge & & & -0.0408 & -1.38 & & & -0.0093 & -0.31 \\
\hline ROA & & & & & -2.9437 & $-20.12 * * *$ & -2.9699 & $-19.87 * * *$ \\
\hline SaleG & & & -0.0730 & -1.50 & -0.1142 & $-2.39 * *$ & -0.1153 & $-2.39 * *$ \\
\hline DebtR & & & & & 1.8022 & $15.34 * * *$ & 1.8806 & $13.22 * * *$ \\
\hline Zscore & & & -0.0176 & $-5.34 * * *$ & 0.0371 & $9.14 * * *$ & 0.0377 & $9.17 * * *$ \\
\hline STD_ROA & & & 8.8769 & $17.38 * * *$ & 4.2118 & $7.62 * * *$ & 4.1825 & $7.54 * * *$ \\
\hline $\mathrm{KZ}$ & & & & & & & -0.0202 & -0.97 \\
\hline Year & Yes & & Yes & & Yes & & Yes & \\
\hline Ind & Yes & & Yes & & Yes & & Yes & \\
\hline Adj R-Sq & 0.0120 & & 0.0379 & & 0.0572 & & 0.0571 & \\
\hline $\mathrm{N}$ & 32,908 & & 32,908 & & 32,908 & & 32,908 & \\
\hline
\end{tabular}

Panel B Sub-sample: controlling stock rating

\begin{tabular}{lcccccc} 
Stock rating & \multicolumn{2}{c}{ Low } & \multicolumn{2}{c}{ Median } & \multicolumn{2}{c}{ High } \\
Variable & Coef. & $\mathrm{t}$ & Coef. & $\mathrm{t}$ & Coef. & $\mathrm{t}$ \\
\hline Intercept & -3.2675 & $-5.83 * * *$ & -1.8604 & $-5.33 * * *$ & -0.8919 & $-2.51 * *$ \\
RSIZE & -0.0897 & $-5.28 * * *$ & -0.0437 & $-3.99 * * *$ & -0.0349 & $-3.43 * * *$ \\
BM & 1.2231 & $11.74 * * *$ & 1.0420 & $12.10 * * *$ & 0.5948 & $6.12 * * *$ \\
LogFirmAge & -0.0120 & -0.18 & 0.0100 & 0.23 & -0.0202 & -0.47 \\
ROA & -3.8245 & $-10.25 * * *$ & -2.4915 & $-10.75 * * *$ & -2.5307 & $-13.03 * * *$ \\
SaleG & -0.0333 & -0.27 & -0.1276 & $-1.72 *$ & -0.0256 & -0.41 \\
DebtR & 2.8906 & $9.44 * * *$ & 1.5808 & $7.30 * * *$ & 0.8589 & $4.08 * * *$ \\
Zscore & 0.0658 & $6.02 * * *$ & 0.0354 & $5.73 * * *$ & 0.0145 & $2.68 * * *$ \\
STD_ROA & 5.5947 & $4.43 * * *$ & 2.7669 & $3.27 * * *$ & 3.0956 & $3.98 * * *$ \\
KZ & -0.0179 & -0.39 & -0.0439 & -1.40 & 0.0092 & 0.31 \\
Year & Yes & & Yes & & Yes & \\
Ind & Yes & & Yes & & Yes \\
Adj R-Sq & 0.0705 & 0.0514 & & 0.0400 \\
N & 10,681 & & 11,272 & & 10,955 \\
\hline
\end{tabular}

Note: This table provides regression results of model (2). The dependent variable is Bias which is the mean difference between consensus earnings forecast and actual earnings of firm $\mathrm{i}$ in year $\mathrm{t}$. RSize is a decile ranking variable that corresponds to the levels of firms' total asset from low to high; $\mathrm{BM}$ is book to market ratio; LogFirmAge is logarithm of firm age; ROA is return on asset; SaleG is sales growth rate; DebtR is debt ratio, Zscore is Z-score to measure financial risk developed by Altman's (1968), STD_ROA is volatility of a firm's quarterly ROA, $\mathrm{KZ}$ is KZ index to measure capital constraints develop by Kaplan and Zingales (1997). ***,**,* indicate statistical significance at the 1 percent, 5 percent, and 10 percent two-tailed confidence levels, respectively. 


\section{Conclusion}

Financial analysts gather corporate social performance information and transmit it to investors through their research reports, and numerous investors rely heavily on analyst research to make investment decisions. This study investigates whether analysts issue favorable research reports for small stocks and how these small stocks perform in subsequent year. The study further examines stock performance and operating performance in the following year to determine whether analysts choose qualified and profitable small stocks for investors.

Analysts tend to follow large and growth stocks, the stocks of large firms attract many analysts; their benefits include trading commissions and potential consulting or underwriting business. However, large institutions are less likely to purchase small stocks due to insufficient information and their size. This makes analysts reluctant to include such stocks in their research portfolios. Therefore, analyses of small stocks reflect the stocks' potential, leading to better ratings. Specifically, analysts must convey good news about small stocks to induce hesitant investors to invest in them and thus earn higher commissions. This study empirically shows that analysts are more likely to issue favorable recommendations and earnings growth forecasts for small stocks. This study's empirical results also show that the performance of small stocks in the following year is better than that of other stocks, while the operating performance of small stocks is not the case. These inconsistent results indicate that financial analysts tend to recommend undervalued stocks, but this may not imply that the operating performance of these stocks will improve the following year.

The findings in this study enrich the literature by deepening our understanding of small stocks and helping investors make better investment decisions. Being able to interpret analyst reports correctly is crucial for investors' investment decisions. However, since I/B/E/S database do not disclose brokerage names, this study confronts with a limitation that the study cannot control more brokerage characteristics that may influence the findings in this study.

\section{References}

Alford, A. W., \& Berger, P. G. (1999). A simultaneous equations analysis of forecast accuracy, analyst following, and trading volume. Journal of Accounting, Auditing \& Finance, 14(3), 219-240. https://doi.org/10.1177/0148558X9901400303

Altman, E. I. (1968). Financial ratios, discriminant analysis and the prediction of corporate bankruptcy. The journal of finance, 23(4), 589-609. https://doi.org/ 10.1111/j.1540-6261.1968.tb00843.x

Arya, A., \& Mittendorf, B. (2007). The interaction among disclosure, competition between firms, and analyst following. Journal of Accounting and Economics, 43(2), 321-339. https://doi.org/10.1016/j.jacceco.2006.11.001

Bhushan, R. (1989). Collection of information about publicly traded firms: Theory and evidence. Journal of Accounting and Economics, 11(2-3), 183-206. https://doi.org/10.1016/0165-4101(89)90005-0

Bradley, D., Gokkaya, S., \& Liu, X. (2017). Before an analyst becomes an analyst: Does industry experience matter?. The Journal of Finance, 72(2), 751-792. https://doi.org/ 10.1111/jofi.12466

Carhart, M. M. (1997). On persistence in mutual fund performance. The Journal of Finance, 52(1), 57-82. https://doi.org/ 10.1111/j.1540-6261.1997.tb03808.x

Caylor, M., Cecchini, M., \& Winchel, J. (2017). Analysts' qualitative statements and the profitability of favorable investment recommendations. Accounting, Organizations and Society, 57, 33-51. https://doi.org/10.1016/j.aos.2017.03.005

Chen, H. K., \& Liang, W. L. (2016). Do venture capitalists improve the operating performance of IPOs? International Review of Economics \& Finance, 44, 291-304. https://doi.org/10.1016/j.iref.2015.12.009

Claus, J., \& Thomas, J. (2001). Equity premia as low as three percent? Evidence from analysts' earnings forecasts for domestic and international stock markets. The Journal of Finance, 56(5), 1629-1666. https://doi.org/ $10.1111 / 0022-1082.00384$

Demiroglu, C., \& Ryngaert, M. (2010). The first analyst coverage of neglected stocks. Financial Management, 39(2), 555-584. https://doi.org/ 10.1111/j.1755-053X.2010.01084.X

Diether, K. B., Malloy, C. J., \& Scherbina, A. (2002). Differences of opinion and the cross section of stock returns. The Journal of Finance, 57(5), 2113-2141. https://doi.org/ 10.1111/0022-1082.00490

Easton, P. D., \& Sommers, G. A. (2007). Effect of analysts' optimism on estimates of the expected rate of return implied by earnings forecasts. Journal of Accounting Research,45(5), 983-1015. https://doi.org/ 10.1111/j.1475-679X.2007.00257.x 
Fama, E. F., \& French, K. R. (1992). The cross - section of expected stock returns. The Journal of Finance, 47(2), 427-465. https://doi.org/ 10.1111/j.1540-6261.1992.tb04398.x

Fama, E. F., \& French, K. R. (1993). Common risk factors in the returns on stocks and bonds. Journal of Financial Economics, 33(1), 3-56. https://doi.org/10.1016/0304-405X(93)90023-5

Firth, M., Lin, C., Liu, P., \& Xuan, Y. (2013). The client is king: do mutual fund relationships bias analyst recommendations?. Journal of Accounting Research, 5l(1), 165-200. https://doi.org/ 10.1111/j.1475-679X.2012.00469.x

Fortin, R., \& Roth, G. (2011). Analyst coverage of small cap firms in a period of brokerage firm retrenchment. Journal of Business \& Economics Research, 5(12), 61-68. https://doi.org/10.19030/jber.v5i12.2616

Hayes, R. M. (1998). The impact of trading commission incentives on analysts' stock coverage decisions and earnings forecasts. Journal of Accounting Research, 36(2), 299-320. https://doi.org/ 10.2307/2491479

He, J. J., \& Tian, X. (2013). The dark side of analyst coverage: The case of innovation. Journal of Financial Economics, 109(3), 856-878. https://doi.org/ 10.1016/j.jfineco.2013.04.001

Hong, H., \& Kubik, J. D. (2003). Analyzing the analysts: Career concerns and biased earnings forecasts. The Journal of Finance, 58(1), 313-351. https://doi.org/ 10.1111/1540-6261.00526

Ioannou, I., \& Serafeim, G. (2015). The impact of corporate social responsibility on investment recommendations: Analysts' perceptions and shifting institutional logics. Strategic Management Journal, 36(7), 1053-1081. https://doi.org/10.1002/smj.2268

Kaplan, S. N., \& Zingales, L. (1997). Do investment-cash flow sensitivities provide useful measures of financing constraints?. The quarterly journal of economics, 112(1), 169-215. https://doi.org/10.1162/003355397555163

Lang, M. H., Lins, K. V., \& Miller, D. P. (2004). Concentrated control, analyst following, and valuation: Do analysts matter most when investors are protected least?. Journal of Accounting Research, 42(3), 589-623. https://doi.org/ 10.1111/j.1475-679X.2004.t01-1-00142.x

Langberg, N., \& Sivaramakrishnan, K. (2008). Voluntary disclosures and information production by analysts. Journal of Accounting and Economics, 46(1), 78-100. https://doi.org/10.1016/j.jacceco.2007.11.004

Lee, C. M., \& So, E. C. (2017). Uncovering expected returns: Information in analyst coverage proxies. Journal of Financial Economics, 124(2), 331-348. https://doi.org/10.1016/j.jfineco.2017.01.007

Lehavy, R., Li, F., \& Merkley, K. (2011). The effect of annual report readability on analyst following and the properties of their earnings forecasts. The Accounting Review, 86(3), 1087-1115. https://doi.org/10.2308/accr.00000043

Luo, X., Wang, H., Raithel, S., \& Zheng, Q. (2015). Corporate social performance, analyst stock recommendations, and firm future returns. Strategic Management Journal, 36(1), 123-136. https://doi.org/ 10.1002/smj.2219

McNichols, M., \& O'Brien, P. C. (1997). Self-selection and analyst coverage. Journal of Accounting Research, 35, 167-199. https://doi.org/ 10.2307/2491460

Merkley, K., Michaely, R., \& Pacelli, J. (2017). Does the scope of the sell - side analyst industry matter? An examination of bias, accuracy, and information content of analyst reports. The Journal of Finance, 72(3), 1285-1334. https://doi.org/10.1111/jofi.12485

Mikhail, M. B., Walther, B. R., \& Willis, R. H. (2007). When Security Analysts Talk, Who Listens?. The Accounting Review, 82(5), 1227-1253. https://doi.org/10.2308/accr.2007.82.5.1227

O'Brien, P. C., \& Tan, H. (2015). Geographic proximity and analyst coverage decisions: Evidence from IPOs. Journal of Accounting and Economics, 59(1), 41-59. https://doi.org/10.1016/j.jacceco.2014.11.002

Rees, L., Sharp, N. Y., \& Wong, P. A. (2017). Working on the weekend: Do analysts strategically time the release of their recommendation revisions? Journal of Corporate Finance, 45, 104-121. https://doi.org/10.1016/j.jcorpfin.2017.04.010

Rubin, A., Segal, B., \& Segal, D. (2017). The interpretation of unanticipated news arrival and analysts' skill. Journal of Financial and Quantitative Analysis, 52(4), 1491-1518. https://doi.org/10.1017/S0022109017000539

Schipper, K. (1991). Analysts' forecasts. Accounting horizons, 5(4), 105.

Yu, F. F. (2008). Analyst coverage and earnings management. Journal of Financial Economics, 88(2), 245-271. https://doi.org/10.1016/j.jfineco.2007.05.008 